\title{
A Tool for Reliable Detection of Aflatoxin Biosynthetic Gene Clusters in Aflatoxigenic and Atoxigenic Aspergillus flavus Isolates
}

\author{
Alfred Mitema ${ }^{1}$, Naser Aliye Feto ${ }^{1,}$, , Sheila Okoth ${ }^{2}$, Mohamed Suhail Rafudeen ${ }^{3, *}$
}

${ }^{1}$ OMICS Research Group, Department of Biotechnology, Vaal University of Technology, South Africa; ${ }^{2}$ School of Biological Sciences, University of Nairobi, Kenya; ${ }^{3}$ Plant Stress Laboratory, Department of Molecular and Cell Biology, University of Cape Town, South Africa.

*Correspondence: anaser22@yahoo.com/naserf@vut.ac.za or suhail.rafudeen@uct.ac.za

\begin{abstract}
Molecular techniques and phenotypic characterisation have been used to differentiate aflatoxigenic and atoxigenic Aspergillus flavus strains. However, there is a lack of a consistent and reliable tool for discrimination between these strains of $A$. flavus. Here we report, an optimised real-time qPCR-based tool for reliable differentiation between aflatoxigenic and atoxigenic strains of $A$. flavus. Accordingly, expression profiles and deletion patterns of genes responsible for aflatoxin production in five representative aflatoxigenic and atoxigenic $A$. flavus strains (KSM012, KSM014, HB021, HB026 and HB027) were examined using the optimised real-time qPCR tool. We observed that under induced conditions, aflP, aflS, aflR and aflO transcripts were the most upregulated genes across the tested isolates while aflS and aflO were always expressed in both induced and uninduced isolates. However, aflR and aflP did not give clear distinctions between non-toxin and toxin producing isolates. The deletion patterns were prominent for aflD and aflR whereas alfO, aflS and aflP had no deletions among the isolates. Significant variation in transcript abundance for aflD, aflR and aflS were observed for aflatoxigenic isolate KSM014 under induced and uninduced states. False detection of aflD gene transcript in atoxigenic strain KSM012 was evident in both induced and uninduced conditions. With the exception of KSM012, aflP gene did not exhibit significant variation in expression in the isolates between induced and uninduced conditions. One-way ANOVA and Post-test analysis for linear trends revealed that aflatoxin biosynthetic cluster genes show significant $(\mathrm{P}<0.05)$ differences between atoxigenic and aflatoxigenic isolates. Our optimized qPCR-based tool reliably discriminated between aflatoxigenic and atoxigenic $A$. flavus isolates and could complement existing detection methods.
\end{abstract}

Keywords: Aspergillus flavus; aflatoxins; structural and regulatory genes; biosynthetic gene clusters; deletion patterns 


\section{Introduction}

Certain fungi of the Aspergillus genus produce secondary metabolites termed aflatoxins, which are a class of naturally-occurring mycotoxins (1). About 200 species of Aspergillus have been identified, of which 16 have been found to produce aflatoxins that are detrimental to both human and animals $(1,2)$. A number of Aspergillus species such as Aspergillus flavus, Aspergillus bombycis, Aspergillus nomius and Aspergillus niger produce aflatoxins with high carcinogenic activity $(3,4)$. Aflatoxin contamination has been detected in maize, beans, cottonseed, peanuts and other grain crops $(5,6)$. The contamination not only results in reduced crop value but can cause health problems in both humans and animals that consume contaminated crops and feeds (7).

Although aflatoxin-producing Aspergillus species are found worldwide, they are of greater concern in underdeveloped countries which lack appropriate infrastructure, management tools and resources required to prevent, control or monitor their impact on the wider community (1). Environmental conditions: unseasonal rains during harvesting, increased temperatures and moisture promotes fungal pathogen proliferation and mycotoxin production $(8,9)$. Additionally, increased risks of mycotoxin production and fungal growth is facilitated by improper harvesting, poor storage facilities and sub-optimal temperatures during processing and marketing. These environmental conditions and problems associated with food production and storage are common in most parts of sub-Saharan Africa, where to date, the largest poisoning of mycotoxin epidemic has been reported $(10,11)$.

The classification and identification of Aspergillus spp. based on phenotype is complemented by molecular and chemotaxonomic characterisation (12,13). Phenotypic characterisation of $A$. flavus isolates may identify an isolate as potentially aflatoxigenic, but this is neither definitive nor precise $(14,15)$. Molecular techniques, such as Reverse Transcriptase Polymerase Chain Reaction (RT-PCR) have also been used to differentiate aflatoxigenic from atoxigenic A. flavus strains, using the expression of regulatory and structural aflatoxin pathway genes as markers for aflatoxin production $(16,17)$. Despite the complexity of the aflatoxin pathway involving at least 25 structural and two regulatory genes (18), some studies have found good agreement between gene expression and aflatoxin production (17). Scherm et al. (17), reported the expression profiles of the genes $a f l O$, aflP and aflD were linked with the A. flavus strains capability for aflatoxins production.

In A. flavus, expression of nor-1 (aflD), the gene that encodes for an enzyme meant to catalyse the conversion of the first stable biosynthesis of aflatoxins, (Fig. S1) norsolorinic acid, to averantin $(19,20)$ is the main structural gene in biosynthetic pathway of aflatoxins. Previous studies established the transcription of aflD as a better marker for discrimination between atoxigenic and aflatoxigenic strains $(21,22)$. In contrast, aflR transcription, which expresses a regulator which is capable of activating majority of structural genes in the aflatoxin biosynthetic pathway had poor discriminatory power (23).

The aflS gene codes for regulatory protein, laeA (24) whose function is not confirmed though, (25) postulated that the interaction between $a f l R$ with laeA may support binding of DNA by the former. Du et al. and Schmidt-heydt et al. $(26,27)$, also observed that aflS may have the ability in modulation of aflR activity and that environmental factors may influence the ratio of aflR to aflS. According to (28), in the case of some Aspergillus spp., this modulation may have shifted the affinity of aflR towards the G-group-specific genes, ordA, $\operatorname{cyp} A$ and nadA, and activated their expression under environmental factors. 

most atoxigenic A. flavus strains, the specific genetic mechanisms resulting in atoxigenicity have not been elucidated in great detail (29).

In the current study, the expression profiles of genes responsible for aflatoxin production in five aflatoxigenic and atoxigenic $A$. flavus strains (KSM012, KSM014, HB021, HB026 and HB027) were examined by real-time qPCR. The isolates were chosen from four different climatic regions of Kenya based on certain

7 morphological and phenotypic characteristics (30).

\section{$8 \quad$ Results}

\section{RNA extraction}

The RNA extracted from A. flavus strains cultivated on YES and YEP medium had acceptable 260/280 ratios (Table S1). The RNA was of good quality and integrity as seen by clear ribosomal RNA bands (Fig.1a). Additionally, there was successful cDNA synthesis, indicated by a continuous smooth cDNA smear (Fig.1b).

\section{Aflatoxin biosynthetic gene cluster and amplicon sizes}

We measured the expression profiles of regulatory and structural genes responsible for aflatoxin production in selected aflatoxigenic and atoxigenic $A$. flavus strains using real-time qPCR. Five specific isolates of A. flavus previously deposited (31) in NCBI GenBank: (KSM012_MG385137, KSM014_MG385138, HB021_MG430317, HB026_MG430319 and HB027_MG430322) were chosen based on their sample location in Kenya together with their S and L-morphotype and ability to produce sclerotia. We used six sets of primers (Table 1) to detect the presence or absence of aflatoxin genes in the induced or un-induced isolates. The cDNA from the respective A. flavus isolates from both induced and uninduced states were subject to qPCR with primers specific for genes in the aflatoxin gene cluster (Fig.2; Table 1). Amplicon sizes exhibited by A. flavus isolates were 120, $116,117,123,168$, and 118 bp for aflO, aflD, aflS, aflP, aflR and $\beta$-Tub, respectively (Fig.2a-f). 
Table 1 Different gene expression profiles or deletion patterns exhibited by Aspergillus flavus strains.*

\begin{tabular}{|c|c|c|c|c|c|c|c|c|c|c|c|}
\hline \multirow[b]{2}{*}{ Isolates } & \multirow[b]{2}{*}{ County } & \multirow[b]{2}{*}{ Strain } & \multicolumn{3}{|c|}{ Sclerotia } & \multicolumn{6}{|c|}{ Mean normalised $C t$ value ratios $\left(\log _{10}\right)$} \\
\hline & & & UV 365nm & $\mathbf{S}$ & $\mathbf{L}$ & Status & aflP & aflD & aflo & aflR & aflS \\
\hline \multirow[t]{2}{*}{12} & KSM & atoxigenic & green & - & - & induced & $0.150 \pm 0.017$ & $0.117 \pm 0.008$ & $0.059 \pm 0.012$ & $-0.007 \pm 0.010$ & $0.034 \pm 0.010$ \\
\hline & & & & & & Uninduced & $0.093 \pm 0.032$ & $0.099 \pm 0.003$ & $-0.067 \pm 0.004$ & $-0.027 \pm 0.006$ & $0.033 \pm 0.004$ \\
\hline \multirow[t]{2}{*}{14} & KSM & aflatoxigenic & blue & ++ & - & induced & $0.254 \pm 0.029$ & $0.278 \pm 0.007$ & $0.139 \pm 0.011$ & $0.144 \pm 0.024$ & $0.233 \pm 0.008$ \\
\hline & & & & & & Uninduced & $0.218 \pm 0.065$ & DL & $0.181 \pm 0.010$ & DL & $0.259 \pm 0.007$ \\
\hline \multirow[t]{2}{*}{21} & HB & afl/atoxigenic & blue/green & - & - & induced & $0.177 \pm 0.006$ & DL & $0.113 \pm 0.003$ & DL & $0.153 \pm 0.011$ \\
\hline & & & & & & Uninduced & $0.112 \pm 0.026$ & DL & $-0.066 \pm 0.003$ & DL & $0.024 \pm 0.004$ \\
\hline \multirow[t]{2}{*}{26} & HB & afl/atoxigenic & blue/green & - & ++ & induced & $0.089 \pm 0.007$ & DL & $0.029 \pm 0.012$ & DL & $0.069 \pm 0.004$ \\
\hline & & & & & & Uninduced & $0.137 \pm 0.013$ & DL & $-0.051 \pm 0.004$ & DL & $0.012 \pm 0.006$ \\
\hline \multirow[t]{2}{*}{27} & HB & afl/atoxigenic & blue/green & - & ++ & induced & $0.130 \pm 0.022$ & DL & $0.078 \pm 0.056$ & DL & $0.175 \pm 0.004$ \\
\hline & & & & & & Uninduced & $0.109 \pm 0.008$ & $\mathrm{DL}$ & $-0.051 \pm 0.004$ & DL & $0.036 \pm 0.010$ \\
\hline
\end{tabular}

* Threshold cycle value ratios, mean \pm standard deviation error based on three biological replicates.

DL: deletion

- or ++: absence or presence of sclerotia

$\mathbf{S}$ or L-morphotype of sclerotia

KSM: Kisumu

HB: Homa Bay 


\section{qPCR and primer efficiency analysis}

The amplicons generated by qPCR showed that the primers (Table 1) were specific, appropriately designed, and suitable for studying A. flavus and aflatoxin genes (Tables 1;2). The aflR and aflD had unique expression profiles and deletion patterns (Table 1; Fig.2). The standard melt curves exhibited statistical linear regression values and efficiency range (Table 2). 
Table 2 Clustered aflatoxin biosynthesis pathway genes showing enzymes involved, functions, statistical linear regression and efficiency.

\begin{tabular}{|c|c|c|c|c|c|}
\hline Genes & Target gene & Enzyme/product & Function in the pathway & $\begin{array}{l}\text { Regression } \\
\text { coefficient }(r)\end{array}$ & Efficiency \\
\hline$\beta$-tub & & & Reference housekeeping gene & 0.99 & 0.32 \\
\hline aflO & $o m t B$ & $O$-methyltransferase $B$ & $\begin{array}{l}D H D M S T \text { (dihydrodemethylsterigmatocystin) } \rightarrow D H S T \\
\text { (dihydrosterigmatocystin) }\end{array}$ & 0.86 & 0.44 \\
\hline aflR & aflR & Transcription activator & Pathway regulator & 0.82 & 0.32 \\
\hline aflS & aflJ & Transcription enhancer & Pathway regulator & 0.82 & 0.80 \\
\hline aflP & omtA & $O$-methyltransferase $A$ & sterigmatocystin $(S T) \rightarrow O$-methylsterigmatocystin $(O M S T)$ & 0.59 & 1.51 \\
\hline$a f l D$ & norl & NOR reductase & norsolorinic acid $(N O R) \rightarrow$ averantin $(A V N)$ & 0.64 & 0.12 \\
\hline
\end{tabular}


When uninduced, aflD and aflR exhibits the deletion pattern for A. flavus strains HB021, HB026, HB027, and KSM014 (Table 2, Figs. 2; 3a; 4c). These genes were expressed by KSM012 under induced and uninduced conditions and KSM014 under induced conditions (Table 2). In contrast, the aflP, aflS and aflO genes were expressed by all five $A$. flavus strains under both induced and uninduced conditions. From the observation, it can be suggested that these aflP, aflS and aflO expression are not ideal indicators for determining whether a strain can synthesize aflatoxins.

\section{Aflatoxin biosynthesis pathway gene cluster expression profiles}

Expression profiles of the structural genes (aflO, aflP, aflD) and regulator genes (aflS, aflR) were analysed. One-way analysis of variance (1-way ANOVA) and a Post-test for linear trend confirmed significant differences $(\mathrm{P}<0.05)$ between atoxigenic and aflatoxigenic isolates for some of the isolates (Fig.3; 4).

Tukey's Multiple Comparison Test (TMCT) revealed significant variances for different biosynthetic genes (Figs.3; 4).

\section{Discussion}

The designed primers were suitable for the current study and our findings (Tables 1; 2; 3 and Fig.2) were similar to previously reported studies $(27,32)$ who found that decreased aflD (nor-1) expression was correlated with a subsequent decrease in aflatoxin production in an aflatoxigenic strain. The aflD is an important gene in the biosynthesis pathway in both A. flavus and A. parasiticus $(19,22)$. The inhibition or disruption of alfD gene expression results in the accumulation of intermediates in aflatoxin biosynthesis such as norsolorinic acid and prevents the synthesis of aflatoxins and any other intermediates in the pathway (33). Similarly $(27,32)$ observed that the disruption of aflatoxin production occurs if specific inhibitor (enzyme) blocks the biosynthesis pathway. Scherm et al. (17), also found that a reduction in aflatoxin level was accompanied by a decrease in $a f l D$ transcripts. Furthermore they found that the expression profiles of aflD (nor-1), aflO (omtB) and aflP (omtA) were consistently correlated with the production of aflatoxins, whereas the expression of aflS (aflJ) and aflR were not.

Data analysis from Table 2 showed that aflP, aflS and aflO gene expression is not essential for determining whether a strain can synthesize aflatoxins. Cary \& Ehrlich (23), established that aflR is a regulatory gene of the pathway intricated in transcription and activation of majority of the aflatoxin biosynthetic structural genes. Schmidt-Heydt et al. (24), found that the ratio between regulatory genes aflS and aflR that is activated by environmental factors. Schmidt-heydt et al. and Abdel-Hadi et al. $(22,27)$ demonstrated the potential transcription of $a f l D$ as a marker to distinguish aflatoxin producing and non-producing isolates from peanut, while aflR expression could not be used to differentiate these phenotypes.

In the current study, an aflatoxin producing strain KSM014, consistently had higher transcript levels than the other isolates across all the studied genes (Figs.3; 4). For aflR and aflD, there was no significant increase in transcript abundance in isolate KSM014 (uninduced state). The aflO and aflS genes were expressed at higher levels in the uninduced state than in the induced (Figs. 3b; 4e). This observation suggests that there could be a relationship between aflO (structural gene) and aflS (regulatory gene). Furthermore, aflO expression was 
significantly lower under induced conditions than uninduced conditions (Fig.4e). aflO expression decreased in uninduced isolates of KSM012, HB021, HB026 and HB027 but increased for isolate KSM014 (Fig.4e).

Expression of the aflP gene did not vary significantly between induced and uninduced isolates KSM014, HB021, HB026 and isolate HB027 according to 1-Way ANOVA and TMCT test (Fig.4d). aflP expression was significantly higher for isolate KSM012 in both induced and un-induced states. Expression in the uninduced isolate, HB026 was higher than in the induced isolate, but the difference was not significant based on a TMCT test. This observation suggests that aflP is not a promising marker that can be used in discrimination of aflatoxigenic and atoxigenic isolates (Fig.4d). aflD, aflR and aflS all differed significantly in expression in KSM014 between induced and uninduced states (Figs.3; 4).

The aflD gene transcript was detected in both induced and uninduced isolate KSM012, which is atoxigenic (Fig.4c; Table 2). False positive and negative transcription signals have been previously observed (34). Biosynthesis of aflatoxin in Aspergillus is regulated by sophisticated pattern of negative and positive transcriptional regulatory factors, that are sensitive to both external and internal stimuli (34). Chiou et al. (2002), postulated that chromosomal position of important genes may take part in gene expression of aflatoxin, and that, PCR based screening techniques involving genes in the aflatoxin biosynthesis pathway may flop in distinguishing atoxigenic and aflatoxigenic strains from one another.

Chang et al. (36), found that all A. flavus strains, both atoxigenic and aflatoxigenic carry aflD, aflP and aflR. This result indicates that the absence of production of aflatoxin in some isolates is due to degeneration of the entire cluster genome. The loss of production of AFB1 and AFB2 by many atoxigenic A. flavus isolates is not due to large deletions, but could also arise from point mutations (36).

Moreover, real time-PCR outcomes have indicated that transcription of aflD may be used as an indicator in discrimination of aflatoxin and non-aflatoxin producers, while aflR and aflP did not discriminate aflatoxigenic and non-aflatoxigenic strains (17). Similarly, they further observed that nor-1, gave good correlation of aflatoxin production and gene expression on non-inducing and inducing media. Their findings contrasts to that of (37), wherein the study involved expression analyses of aflO and aflD genes, in Aspergillus section Flavi isolates (31), native almonds from Portuguese. Their conclusion was that expression of aflD was not a promising marker that could be used in differentiation of non-aflatoxigenic and aflatoxigenic isolates. There was only one almond isolate in their study that gave false positive transcript. We have also observed in the current study that $a f l D$ and $a f l R$ transcripts were not consistent in giving a clear distinction between aflatoxigenic and atoxigenic strains, which is in line with a related finding by (37). This could be due to either point mutations or large deletions in the aflatoxin genome cluster involved in aflatoxin production (Fig.3a; 4c).

Based on our results, aflO might be considered as a marker for distinguishing atoxigenic and aflatoxigenic strains (Fig.4e; Table 2). We used a more sensitive real-time RT-qPCR approach compared to other studies. This involved different marker genes (MEP for maize, $\beta$-tub and Efla for A. flavus) and using SYBR green fluorescence to detect expression. Scherm et al. and Rodrigues et al. $(17,37)$ who obtained contradictory results to each other used the less sensitive RT-PCR method and only the A. flavus $\beta$-tub gene as a marker. Due to the inconsistency of results across research groups, further studies are needed to identify a molecular marker suitable for differentiating atoxigenic and aflatoxigenic strains. The qPCR protocol used in this study gave 
1 promising results and should be recommended in future research especially with A. flavus strains. Criseo et al.

2 (38) also used molecular techniques to distinguish non-aflatoxigenic and aflatoxigenic strains of $A$. flavus through

3 the correlation with the presence or absence of one or several genes in the biosynthesis pathway of aflatoxin.

Studies differentiating aflatoxigenic and atoxigenic strains have often relied on monitoring aflatoxin gene expression with reverse transcription and real-time PCR methodologies (16,39). It is, thus, understandable that lack of a tool/protocol for reliable discrimination between toxigenic and atoxigenic strains of $A$. flavus isolates have not yet been successfully established. Furthermore, one should be aware that some genes are not exclusive to the aflatoxin biosynthetic pathway, which could create false-positives from sterigmatocystin producing fungi (40).

In conclusion, many enzymatic steps are involved in the aflatoxin biosynthesis pathway. Expression level measurements of the genes that codes for the enzymes or the absence/presence of these genes could provide information on whether a strain is aflatoxigenic or not. However, there is disparity in identifying a suitable gene indicator for production of aflatoxin and measuring a strains ability to produce aflatoxin remains the only reliable method. High genetic similarity between species of Aspergillus and high levels of intraspecific genetic variation have hindered reliable identification of molecular markers capable of consistently differentiating various strains and their aflatoxigenic potential and makes the task challenging.

We found that certain genes in the aflatoxin biosynthetic pathway are expressed more highly than others in the same pathway. Accordingly, expression increased the most for aflP, aflS, aflR and $a f l O$. The modifications and optimisation of the RT-qPCR method used in this study enabled better discrimination of the isolates with respect to their possible toxigenicity or non-toxigenicity. We recommend this approach with suggested modifications for future work on reliable discriminating between toxigenic and atoxigenic strains of $A$. flavus isolates.

Materials and methods

Fungal cultures from previous studies (30) were consistently maintained on new PDA plates (Sigma Aldrich, USA) complemented with chloramphenicol for inhibition of bacterial growth. Mono-conidial bacterial cultures were cultivated by taking a small quantity of mycelium and transferring into $1000 \mu 1$ of sterile water. One hundred microliters of the inoculum were then transferred onto the water agar (WA) plate, swirled for a few seconds with conidial suspension and liquid culture discarded off the plate, thereafter, the plate was incubated for $12 \mathrm{hrs}$ at RT. Mono-conidial cultures were assessed under stereomicroscope (Nikon Corp., Japan), excised, relocated onto new PDA plates and incubated at $25^{\circ} \mathrm{C}$ in the dark. For aflatoxin induction, each Aspergillus isolate was grown in non-inducing medium yeast extract peptone (YEP) (Sigma Aldrich, USA) and aflatoxin-inducing medium yeast extract agar (YES) (Sigma Aldrich, USA) plates and incubated for 5 days at $25{ }^{\circ} \mathrm{C}$ prior to ribonucleic acid (RNA) extraction.

\section{Total RNA extraction}

RNA was extracted from each $A$. flavus isolates grown on medium (YEP and YES) respectively. Mycelia were scrapped off the plates, flash frozen and ground in liquid nitrogen in a sterile pestle and mortar. 
Approximately 200-300 mg of ground mycelium was flooded with TrizoL ${ }^{\circledR}, 750 \mu 1$ (Sigma Aldrich, USA) in 2 $\mathrm{ml}$ tubes containing $0.3 \mathrm{~mm}$ diameter glass beads (Merck KGaA, Darmstadt, Germany). The mixture was vortexed, thereafter incubated for $10 \mathrm{~min}$ at room temperature (RT) range $21-23{ }^{\circ} \mathrm{C}$. Chloroform $(200 \mu \mathrm{l})($ Sigma Aldrich, USA) was added to the homogenized sample and mixed gently for $1 \mathrm{~min}$. The tubes were incubated for $5 \mathrm{~min}$ at RT, followed by centrifugation for $15 \mathrm{~min}(14000 \mathrm{x} \mathrm{g})$ at $4{ }^{\circ} \mathrm{C}$ (Beckman Coulter, Inc USA). The aqueous phase was transferred to a fresh $1.5 \mathrm{ml}$ tube and the organic phase was kept for deoxyribonucleic acid (DNA) and protein extraction at $-80{ }^{\circ} \mathrm{C}$. Isopropanol $(500 \mu \mathrm{l})$ (Sigma Aldrich, USA) was added to the aqueous phase and incubated for $10 \mathrm{~min}$ at RT to allow RNA precipitation. The mixture was then centrifuged for $10 \min (14000 \mathrm{x} \mathrm{g})$ at $4{ }^{\circ} \mathrm{C}$ and the supernatant discarded. The pellets were washed in $1 \mathrm{ml}$ of cold $75 \%$ ethanol (Sigma Aldrich, USA) for $1 \mathrm{~min}$, then centrifuged for $5 \mathrm{~min}(14000 \mathrm{xg})$ at $4{ }^{\circ} \mathrm{C}$. The supernatant was discarded, and the RNA pellet air-dried for $10 \mathrm{~min}$ at RT. The pellets were re-suspended in $100 \mu \mathrm{LEPC}$ water, incubated at $55{ }^{\circ} \mathrm{C}$ for 10-15 min and then stored at $-80^{\circ} \mathrm{C}$ until analysed.

The RNA extracts were then treated with deoxyribonuclease I (DNase I; New England Biolabs, USA) to digest and remove any genomic DNA contaminant as per the manufacturer's instruction. The sample was then purified using the Zymo Research Fungal/Bacterial RNA Miniprep Kit (Inqaba Biotec, South Africa) according to the manufacturer's instructions. The RNA was measured with a Nano Drop ND-1000 spectrophotometer (Nano Drop Technologies, USA) and the integrity was assessed on a $1.2 \%$ agarose/EtBr gel.

\section{First strand cDNA synthesis}

Circa $500 \mathrm{ng}$ of RNA was used for cDNA synthesis. The reaction was performed in triplicate using MMLV Reverse Transcriptase Kit (Promega, USA) according to the manufacturer's instructions with modifications. Briefly, a ratio of 1:1 instead of 1:10 random hexamers to Oligo (dT) was selected for cDNA synthesis from the fungal RNA in order to increase sensitivity. The primer mix (reaction volumes of $10 \mu 1$ consisted of $5 \mu 1$ nuclease free water, $1 \mu 150 \mathrm{ng} / \mathrm{ml}$ Random hexamer, $0.1 \mu \mathrm{l}$ of $500 \mathrm{ng} / \mathrm{ml}$ Oligo dT and $500 \mathrm{ng}$ RNA) was incubated at 70 ${ }^{\circ} \mathrm{C}$ for $5 \mathrm{~min}$ and immediately cooled on ice for $5 \mathrm{~min}$, then briefly centrifuged. The annealed primer mix was added to the master mix (reaction volumes of $14.5 \mu 1$ nuclease free water, $10 \mu 15 \mathrm{X}$ M-MLV reaction buffer, $2 \mu 1$ M-MLV-RT point mutant, $2.5 \mu \mathrm{l}$ dNTP Mix and $1 \mu \mathrm{l}$ inhibitor) in the ratio of 1:3, gently mixed, and then aliquoted onto PCR tubes. The reaction conditions consisted of four cycles of $25^{\circ} \mathrm{C}$ for $20 \mathrm{~min}, 37^{\circ} \mathrm{C}$ for $40 \mathrm{~min}, 42{ }^{\circ} \mathrm{C}$ for $90 \mathrm{~min}$, followed by an incubation at $70{ }^{\circ} \mathrm{C}$ for $15 \mathrm{~min}$ and a final step at $4{ }^{\circ} \mathrm{C}$ for $1 \mathrm{~min}$. To assess for successful cDNA synthesis, samples were initially run on a $1.2 \%(\mathrm{w} / \mathrm{v})$ agarose/EtBr gel at $120 \mathrm{~V}$ for $5 \mathrm{~min}$, thereafter, at 80 $\mathrm{V}$ for $45 \mathrm{~min}$ and visualised as previously described (31). The synthesised samples were combined and stored at $-20{ }^{\circ} \mathrm{C}$ for subsequent use and at $-80{ }^{\circ} \mathrm{C}$ for later analyses.

\section{qPCR and primer design}

To detect the presence or absence of aflatoxin genes in the induced or un-induced isolates, six sets of primers (Table 3) for one reference gene ( $\beta$-tubulin) and five genes of interests (structural and regulatory) were designed and assessed as previously described $(30,41)$. The PCR and melt curve analysis were used to identify both specific and non-specific amplification.

Table 31 List of primers and the corresponding target genes used in the study. 


\begin{tabular}{|c|c|c|c|c|}
\hline \multirow[b]{2}{*}{$\begin{array}{l}\text { Primer } \\
\text { code }\end{array}$} & \multicolumn{4}{|c|}{ Primer sequences* } \\
\hline & $\begin{array}{l}\text { Target } \\
\text { gene }\end{array}$ & Forward Primer & Reverse Primer & $\begin{array}{l}\text { Product } \\
\text { size (bp) }\end{array}$ \\
\hline aflS & aflJ & $\begin{array}{l}\text { CTG CAG CTA TAT TGC CCA } \\
\text { CA } \\
\text { GCC AGG GGT ATT TGT TGG }\end{array}$ & $\begin{array}{l}\text { TAA ACC CAG GCA GAG } \\
\text { TTG GT } \\
\text { TTC TCC CGA GAG CAT }\end{array}$ & 117 \\
\hline aflo & $o m t B$ & TA & CTA GC & 120 \\
\hline aflD & nor-1 & CAC TTG GAC GTG GTG GTT G & $\begin{array}{l}\text { AGG ACG GGA GCA TAC } \\
\text { ATG TT }\end{array}$ & 116 \\
\hline alfR & alfR & $\begin{array}{l}\text { CCG GGA TAG CTG TAC GAG } \\
\text { TT } \\
\text { GGC CGC CGC TTT GAT CTA }\end{array}$ & $\begin{array}{l}\text { GAT GGT CGC CGA GTT } \\
\text { GAA TC }\end{array}$ & 168 \\
\hline alfP & omtA & GG & $\begin{array}{l}\text { ACC ACG AC CGCC GCC } \\
\text { TGT TAC CAG CAC CGG }\end{array}$ & 123 \\
\hline$\beta_{-}$Tub & reference & TCC CTT CGG CAA GCT TTT C & ACT GA & 118 \\
\hline
\end{tabular}

1

\footnotetext{
* All primers had the same annealing temperature $\left(60^{\circ} \mathrm{C}\right)$
} qPCR efficiency

The expression profiles and analysis of the genes were investigated using Rotor Gene 60002 plex HRM (Corbett Life Science Research, Australia). Serial dilutions of pooled cDNA (10-fold) from induced and uninduced isolates were used to generate standard curves. The Kapa SYBR Fast Kit (Kapa BioSystems, South Africa) master mix containing reaction buffer, heat-activated DNA polymerase, dNTPs and a working concentration of $3 \mathrm{mM} \mathrm{MgCl}_{2}$ were used for each qPCR reaction. The reaction consisted of a final concentration of 1 X Kapa SYBR green, $10 \mu \mathrm{M}$ gene specific primers $(0.4 \mu \mathrm{l}), 1 \mu \mathrm{l}$ of cDNA and nuclease free water to a total volume of $20 \mu \mathrm{l}$. The primer sets (Table 1) were used in separate reactions. Each dilution-point reaction was performed in triplicate along with a no-reverse transcription control, and a no-template control (NTC) in each real-time run. Amplification was carried out under the following conditions: $95{ }^{\circ} \mathrm{C}$ for $10 \mathrm{~min}$; and 35 cycles of $95{ }^{\circ} \mathrm{C}$ for $3 \mathrm{~s}, 60^{\circ} \mathrm{C}$ for $20 \mathrm{~s}$, and $72{ }^{\circ} \mathrm{C}$ for $1 \mathrm{~s}$.

\section{Expression stability analysis of aflatoxin biosynthetic genes}

The qPCR reaction mixes and conditions were set up as described previously (30). To minimise variations between qPCR runs, all the reactions containing one primer pair were performed in a single run. The average expression levels were calculated from three technical repeats and by importing the relative standard curve into each run. Relative gene expression was determined by the amplification threshold in the exponential phase of the PCR, identifying the threshold cycle $(\mathrm{Ct})$ value and comparing the $\mathrm{Ct}$ value to the standard curve (42). The stability and potential of the reference genes were evaluated using both GeNorm and NormFinder (GenEx, MultiD, Sweden) based on the Pfaffl equation (43).

\section{Statistics and relative quantification analysis}

The threshold cycle $(\mathrm{Ct})$ values of the gene of interest were normalised to that of the reference gene. The average values calculated were used for relative quantification of the gene of interest. The values obtained for transcript levels were used as a calibrator to determine whether a significant change in expression has occurred. Relative quantification levels were determined with the GenEx software (MultiD, Sweden). The equation describes one sample as the ratio of the gene of interest (target) versus a calibrator sample (control) and the 
1 reference gene (reference) versus a calibrator sample (control). The amplification efficiencies (E) were calculated 2 as: $E=10\left(\frac{-1}{\text { Slope }}\right)$. The difference in $\mathrm{Ct}$ values of the target gene in the control and sample $(\Delta \mathrm{Ct}$ target $)$ and in the 3 reference gene in the control and sample ( $\Delta \mathrm{Ct}$ reference) were considered (43). The equation used to calculate the 4 ratio was:

$$
\text { Ratio }=\frac{\left(E_{\text {target }}\right) \Delta^{C t \text { target (control-sample })}}{\left(E_{\text {reference }}\right) \Delta^{C t \text { reference (control-sample })}}
$$


The experiments were carried out in four biological and three technical replicates. The relative expression level profiles of genes correlated with production of aflatoxins by the isolates were log transformed and assessed. Data analyses were made using GraphPad Prism version 5.02 (GraphPad Software, Inc., USA), One-way analysis of variance (1-way ANOVA), Tukey's Multiple Comparison Test (TMCT), Post-test for linear trend and R statistical software (www.r-project.org), version 3.2.5.

\section{Acknowledgement}

This work was supported by the University Science, Humanities and Engineering Partnerships in Africa (USHEPiA) Fund and South African Bio-Design Initiative (SABDI) grant number 420/01 SABDI 16/1021 secured by Dr NA Feto. Also, the authors acknowledge the University of Nairobi, Kenya and the University of Cape Town and Vaal University of Technology, South Africa for providing laboratory space and funding.

\section{Authors' contribution}

Authors, AM, NAF, MSR: conceived and designed the experiment, AM: generated and analysed the data, and drafted the manuscript. NAF: edited and reviewed the entire manuscript. NAF, SO, and MSR: reviewed the entire manuscript.

\section{Competing interests}

The authors declare no conflict of interest. The authors are responsible for the content and writing of the paper alone.

\section{References}

1. Klich MA. Aspergillus flavus: the major producer of aflatoxin. Mol Plant Pathol [Internet]. 2007;8(6):713-22. Available from: http://doi.wiley.com/10.1111/j.1364-3703.2007.00436.x

2. Rotimi OA, Rotimi SO, Oluwafemi F, Ademuyiwa O, Balogun EA. Coexistence of Aflatoxicosis with Protein Malnutrition Worsens Hepatic Oxidative Damage in Rats. J Biochem Mol Toxicol [Internet]. 2016 Jan 25 [cited 2016 Apr 14];30(6). Available from: http://www.ncbi.nlm.nih.gov/pubmed/26804159

3. Bandyopadhyay R, Kumar M, Leslie JF. Relative severity of aflatoxin contamination of cereal crops in West Africa. Food Addit Contam. 2007;24(10):1109-14.

4. JECFA. Eighty-third report of the Joint FAO/WHO expert committee on food additives. Evaluation of certain contaminants in food. WHO technical report series 1002. 2017.

5. Ventura M, Antonio G, Anaya I, Jordi D, Broto F. Determination of aflatoxins B1, G1, B2 and G2 in medicinal herbs by liquid chromatography - tandem mass spectrometry \&. J Chromatogr A. 2004;1048:25-9.

6. Somashekar DA, Rati ER, Anand S, Chandrashekar A. Isolation, enumeration and PCR characterization of aflatoxigenic fungi from food and feed samples in India. Food Microbiol. 2004;21:809-13.

7. $\mathrm{Wu} \mathrm{F}$, Khlangwiset P. Health economic impacts and cost-effectiveness of aflatoxin reduction strategies in Africa: Case studies in biocontrol and postharvest interventions. Food Addit Contam Part A. 2010;27(4):496-509 Health.

8. Wagacha JM, Muthomi JW. Mycotoxin problem in Africa: current status, implications to food safety and health and possible management strategies. Int J Food Microbiol [Internet]. 2008 May 10 [cited 
2016 Mar 4];124(1):1-12. Available from:

http://www.sciencedirect.com/science/article/pii/S0168160508000305

9. Bhat RV and SV. Mycotoxin Food Safety Risk in Developing Countries. Food Microbiol. 2003;FOCUS $10 \bullet$.

10. Gieseker KE. Outbreak of aflatoxin poisoning- Estern and Central Provinces, Kenya, January-July 2004. Public Heal Fac Publ. 2004;53(34):790-3.

11. Lewis LMO, Henry Njapau, Helen Schurz-Rogers, George Luber SK, Nyamongo J, Lorraine Backer, Abdikher Mohamud Dahiye, Ambrose Mlsore, Kevin DeCock CR, Aflatoxicosis and the K, Investigation, et al. Aflatoxin Contamination of Commercial Maize Products during an Outbreak of Acute Aflatoxicosis in Eastern and Central Kenya. Environ Health Perspect [Internet]. 2005;113(12):1763-7. Available from: http://www.ehponline.org/ambra-doi-resolver/10.1289/ehp.7998

12. Probst C, Schulthess F, Cotty PJ. Impact of Aspergillus section Flavi community structure on the development of lethal levels of aflatoxins in Kenyan maize (Zea mays). J Appl Microbiol [Internet]. 2010;108(2):600-10. Available from: http://www.ncbi.nlm.nih.gov/pubmed/19674186

13. Probst C, Callicott KA, Cotty PJ. Deadly strains of Kenyan Aspergillus are distinct from other aflatoxin producers. Eur J Plant Pathol. 2012;132:419-29.

14. Frisvad JC, Skouboe P, Samson RA. Taxonomic comparison of three different groups of aflatoxin producers and a new efficient producer of aflatoxin $\mathrm{B}<$ inf $>1</$ inf $>$, sterigmatocystin and 3-Omethylsterigmatocystin, Aspergillus rambellii sp. nov. Syst Appl Microbiol. 2005;28(5):442-53.

15. Pildain MB, Frisvad JC, Vaamonde G, Cabral D, Varga J, Samson RA. Two novel aflatoxin-producing Aspergillus species from Argentinean peanuts. Int J Syst Evol Microbiol. 2008;58(3):725-35.

16. Zsuzsanna Mayer a, Angelo Bagnara b, Paul Fa“rber b, Rolf Geisen. Quantification of the copy number of nor-1, a gene of the aflatoxin biosynthetic pathway by real-time PCR, and its correlation to the cfu of Aspergillus flavus in foods. Int J Food Microbiol. 2003;82:143 - 151.

17. Scherm B, Palomba M, Serra D, Marcello A, Migheli Q. Detection of transcripts of the aflatoxin genes aflD, aflO, and aflP by reverse transcription-polymerase chain reaction allows differentiation of aflatoxin-producing and non-producing isolates of Aspergillus flavus and Aspergillus parasiticus. Int J Food Microbiol [Internet]. 2005 [cited 2016 Oct 26];98(2):201-10. Available from: www.elsevier.com/locate/ijfoodmicro

18. Yu J, Bhatnagar D, Cleveland TE. Completed sequence of aflatoxin pathway gene cluster in Aspergillus parasiticus. FEBS Lett [Internet]. 2004;564(1-2):126-30. Available from: http://www.sciencedirect.com/science/article/pii/S0014579304003278

19. Trail F, Chang P-K, Cary J, Lin JE, Linz JE. Structural and Functional Analysis of the nor-i Gene Involved in the Biosynthesis of Aflatoxins by Aspergillus parasiticus. Appl Environ Microbiol. 1994;60(11):4078-85.

20. Zhou R, Linz JE. Enzymatic Function of the Nor-1 Protein in Aflatoxin Biosynthesis in Aspergillus parasiticus Enzymatic Function of the Nor-1 Protein in Aflatoxin Biosynthesis in Aspergillus parasiticus. Appl Environ Microbiol. 1999;65(12):5639-41.

21. Abdel-Hadi A, Carter D, Magan N. Temporal monitoring of the nor-1 (aflD) gene of Aspergillus flavus in relation to aflatoxin B1 production during storage of peanuts under different water activity levels. J Appl Microbiol [Internet]. 2010;109(6):1914-22. Available from: http://doi.wiley.com/10.1111/j.13652672.2010.04820.x

22. Abdel-Hadi A, Carter D, Magan N. Discrimination between aflatoxigenic and non-aflatoxigenic Aspergillus section Flavi strains from Egyptian peanuts using molecular and analytical techniques. World Mycotoxin J [Internet]. 2011;4:69-77. Available from: http://dx.doi.org/10.3920/WMJ2010.1223

23. Cary JW, Ehrlich KC. Generation of aflR disruption mutants of Aspergillus parasiticus. Appl Microbiol 
Biotechnol. 2000;53:680-4.

24. Schmidt-Heydt M, Abdel-Hadi A, Magan N, Geisen R. Complex regulation of the aflatoxin biosynthesis gene cluster of Aspergillus flavus in relation to various combinations of water activity and temperature. Int J Food Microbiol [Internet]. 2009;135(3):231-7. Available from: http://linkinghub.elsevier.com/retrieve/pii/S0168160509003699

25. Yu J, Chang P, Ehrlich KC, Cary JW, Bhatnagar D, Cleveland TE, et al. Clustered Pathway Genes in Aflatoxin Biosynthesis MINIREVIEW Clustered Pathway Genes in Aflatoxin Biosynthesis. Appl Environ Microbiol. 2004;70(3):1253-62.

26. Du W, Obrian GR, Payne GA. Function and regulation of aflJ in the accumulation of aflatoxin early pathway intermediate in Aspergillus flavus. Food Addit Contam. 2007;24(10):1043-50.

27. Schmidt-heydt M, Rüfer CE, Abdel-hadi A, Magan N, Geisen R. The production of aflatoxin B1 or G1 by Aspergillus parasiticus at various combinations of temperature and water activity is related to the ratio of aflS to aflR expression. Mycotox Res. 2010;26(4):241-6.

28. Cai J, Zeng H, Shima Y, Hatabayashi H, Nakagawa H, Ito Y, et al. Involvement of the nadA gene in formation of G-group aflatoxins in Aspergillus parasiticus. Fungal Genet Biol. 2008;45(2008):1081-93.

29. Ehrlich KC, Montalbano BG, Cotty PJ. Analysis of single nucleotide polymorphisms in three genes shows evidence for genetic isolation of certain Aspergillus flavus vegetative compatibility groups. FEMS Microbiol Lett. 2007;268:231-6.

30. Mitema A, Okoth S, Rafudeen MS. Vegetative compatibility and phenotypic characterization as a means of determining genetic diversity of Aspergillus flavus isolates. Fungal Biol. 2018;122(4).

31. Mitema AO. Molecular and Bio-analytical Characterisation as a means to understand Genetic diversity within Kenyan Aspergillus flavus strains [Internet]. University of Cape Town; 2018. Available from: http://hdl.handle.net/11427/28390

32. Ahmed Abdel-Hadi, Markus Schmidt-Heydt, Roberto Parra RG and, Magan N. A systems approach to model the relationship between aflatoxin gene cluster expression, environmental factors, growth and toxin production by Aspergillus flavus. R Soc. 2012;9(69):757-67.

33. Bennett JW. Loss of Norsolorinic Acid and Aflatoxin Production by a Mutant of Aspergillus parasiticus. Microbiology [Internet]. 1981;124(2):429-32. Available from: http://mic.microbiologyresearch.org/content/journal/micro/10.1099/00221287-124-2-429

34. Bhatnagar D, Ehrlich KC, Cleveland TE. Molecular genetic analysis and regulation of aflatoxin biosynthesis. Appl Microbiol Biotechnol [Internet]. 2003;61(2):83-93. Available from: http://www.ncbi.nlm.nih.gov/pubmed/12655449

35. Chiou C-H, Miller M, Wilson DL, Trail F, Linz JE. Chromosomal location plays a role in regulation of aflatoxin gene expression in Aspergillus parasiticus. Appl Environ Microbiol [Internet]. 2002;68(1):306-15. Available from:

http://www.pubmedcentral.nih.gov/articlerender.fcgi?artid=126543\&tool=pmcentrez\&rendertype=abstr act

36. Chang P, Horn BW, Dorner JW. Sequence breakpoints in the a X atoxin biosynthesis gene cluster and X anking regions in nona $X$ atoxigenic Aspergillus X avus isolates. Fungal Genet Biol. 2005;42:914-23.

37. Rodrigues P, Venâncio A, Kozakiewicz Z, Lima N. A polyphasic approach to the identification of aflatoxigenic and non-aflatoxigenic strains of Aspergillus Section Flavi isolated from Portuguese almonds. Int J Food Microbiol [Internet]. 2009;129(2):187-93. Available from: http://linkinghub.elsevier.com/retrieve/pii/S0168160508006156

38. Criseo G, A. Bagnara, G. Bisignano. Differentiation of aflatoxin-producing and non-producing strains of Aspergillus flavus group. Lett Appl Microbiol. 2001;33(4):291-5. 
bioRxiv preprint doi: https://doi.org/10.1101/2021.03.31.437855; this version posted March 31, 2021. The copyright holder for this preprint (which was not certified by peer review) is the author/funder, who has granted bioRxiv a license to display the preprint in perpetuity. It is made available under aCC-BY 4.0 International license.

39. Degola F, Berni E, Dall'Asta C, Spotti E, Marchelli R, Ferrero I, et al. A multiplex RT-PCR approach to detect aflatoxigenic strains of Aspergillus flavus. J Appl Microbiol [Internet]. 2007;103(2):409-17. Available from: http://www.ncbi.nlm.nih.gov/pubmed/17650201

40. Paterson RRM. Identification and quantification of mycotoxigenic fungi by PCR. Process Biochem. 2006;41:1467-74.

41. Untergasser A, Cutcutache I, Koressaar T, Ye J, Faircloth BC, Remm M, et al. Primer3-new capabilities and interfaces. Nucleic Acids Res. 2012;40(15):1-12.

42. Fischer G, Müller T, Schwalbe R, Ostrowski R, Dott W. Species-specific profiles of mycotoxins produced in cultures and associated with conidia of airborne fungi derived from biowaste. Int J Hyg Environ Heal. 2000;116:105-16.

43. Pfaffl MW. Development and validation of an externally standardised quantitative insulin-like growth factor-1 RT-PCR using light cycler SYBR green 1 technology. 2001.

44. Sweeney MJ, Dobson ADW. Molecular biology of mycotoxin biosynthesis. FEMS Microbiol Lett. 1999;175:149-67.

45. Yu J, Chang P, Ehrlich KC, Cary JW, Bhatnagar D, Cleveland TE, et al. Clustered Pathway Genes in Aflatoxin Biosynthesis. Appl Environ Microbiol. 2004;70(3):1253-62.

46. Yu Jiujiang, Ehrlich KC. Aflatoxin Biosynthetic Pathway and Pathway Genes. www.intechopen.com [Internet]. 2012;450. Available from: http://www.intechopen.com/books/salmonella-a-dangerousfoodborne-pathogen/attachment-and-biofilm- formation-by-salmonella-in-food-processingenvironments\%0AInTech

\section{List of figures}

Figure 1. Gel electrophoresis of RNA extracted from selected Aspergillus flavus strains assessed on a $1.2 \%$ agarose/EtBr gel at $80 \mathrm{~V}$ for 45 min showing; (a). Total RNA; Lane: 1. No template (control); Lanes 2. NC05; 3. KSM012; 4. KSM014; 5. HB021; 6. HB025; 7. HB26; 8. HB027; 9. HB028; (b). cDNA synthesis (Lane: 1. KSM012 and 2. KSM014). [(NC: Nandi county, Kenya); (KSM: Kisumu, Kenya); (HB: Homa Bay, Kenya); EtBr: ethidium bromide; cDNA: complementary deoxyribonucleic acid; RNA: ribonucleic acid].

Figure 2. Gel electrophoresis of induced and uninduced isolates of $A$. flavus assessed showing qPCR product amplicon sizes of different genes run at $80 \mathrm{~V}$ for $45 \mathrm{~min}$ on $2 \%$ agarose/EtBr gel displaying various deletion patterns. M: 100 bp low range molecular marker; aflO: Lane 1: NTC; 2. Unind27; 3. Ind27; 4. Unind26; 5. Ind26; 6. Unind21; 7. Ind21; 8. Unind14; 9. Ind14; 10. Unind12; aflD and aflR; Lane 1. NTC; 2. Ind12; 3. Unind12; 4. Ind14; 5. Unind14; 6. Ind21; 7. Unind21; 8. Ind26; 9. Unind26; 10. Ind27; 11. Unind27; 12. noRT; 13. noRT; aflS: Lane 1: NTC; 2. Unind27; 3. Ind27; 4. Unind26; 5. Ind26; 6. Unind21; 7. Ind21; 8. Unind14; 9. Ind14; 10. Unind12; 11. Ind12; 12. NTC; 13. Pldstd3; 14. Pldstd2; 15. Pldstd1; aflP: 1. Pldstd1; 2. Unind27; 3. Ind27; 4. Unind26; 5. Ind26; 6. Unind21; 7. Ind21; 8. Unind14; 9. Ind14; 10. Unind12; 11. Ind12; 12. NTC; $\beta$-Tub: Lane 1: NTC; 2. Unind27; 3. Ind27; 4. Unind26; 5. Ind26; 6. Unind21; 7. Ind21; 8. Unind 14; 9. Ind14; 10. Unind12; 11. Ind12. The isolates were cultured on inducing media (YES) and non-inducing media (YEP) (Unind: Uninduced; Ind: induced and Pldstd: Pooled standard).

Figure 3. Expression profiles for aflR and aflS. a. Significant difference in expression were noted in aflR for isolates 12 and 14 (both induced), with isolate 14 upregulated significantly. Isolates HB021, HBO26 and HB027 displayed no significant expression. Uninduced isolate KSM012 was significantly down regulated. b. aflS expression profiles. The expression values were normalised, and $\log$ transformed $\left(\log _{10}\right)$. Asterisks and the error bars shows significance variance and standard mean deviations $(n=3)$, 1-way ANOVA and Tukey's Multiple Comparison Test ( $<$ 0.05). (KSM: Kisumu; HB: Homa Bay; Unind: uninduced; Ind: induced; 12-27: isolates).

Figure 4. Aflatoxin biosynthetic gene cluster expression profiles. c. aflD expression profiles for Aspergillus flavus KSM012 and KSM014, with isolate KSM014 highly expressed. No expression was observed for isolates HB021, HB026 and HB027. d. aflP expression, which was statistically significant only for isolate KSM012. e. aflO 
expression profiles. There were significant difference for the atoxigenic isolates but not for the toxigenic isolates. Expression values were normalised, and $\log$ transformed $\left(\log _{10}\right)$. [Asterisks and the error bars show significance variance and standard deviations of the mean, 1-way ANOVA and Tukey's Multiple Comparison Test $(\mathrm{P}<0.05)]$. (KSM: Kisumu; HB: Homa Bay; Unind: uninduced; Ind: induced; 12-27: isolates).Significant decreases in aflR transcripts $(\mathrm{P}<0.05)$ were found for strains KSM012, HB021, HB026 and HB027 (Fig. 2.3a). In A. flavus KSM014, an aflatoxin producing strain, aflR transcript abundance increased under induced and decreased under uninduced conditions (Fig.3a). Thus, aflR could be a marker to differentiate toxin and non-toxin producers. When comparing the induced isolates, isolate HB026, had higher levels of expression of aflS and aflO. KSM012 and KSM014 had higher aflD and aflR transcript levels in induced than in uninduced cultures (Figs.3; 4; Table 2). AflR expression decreased significantly in uninduced isolate KSM012 (Fig.3a).

Figure S1. A flow diagram showing clustered genes (a) and the aflatoxin biosynthetic pathway (b). The corresponding enzymes and genes that are concerned with each step in the bioconversion are indicated in panel (a). The vertical line gives a representation of the $82-\mathrm{kb}$ aflatoxin biosynthesis pathway gene clusters and utilization of the sugar gene cluster in Aspergillus flavus. The novel gene names are represented on the left of the vertical line and the ancient gene names are shown on the right side The enzymes involved: fatty acid synthase, polyketide synthase, norsolorinic acid reductase, versiconal hemiacetal acetate reductase, esterase, versicolorin $\mathrm{B}$ synthase, versiconyl cyclase, desaturase, O-methyltransferase (MT-II), O-methyltransferase, O-methyltransferase (MT-I); AFB1: aflatoxin B1; AFB2: aflatoxin B2; AFG1: aflatoxin G1; AFG2: aflatoxin G2 (Adopted from(4446). Asterisks (red star) represents the specific genes studied.

\section{Tables}

Table 1. Different gene expression profiles or deletion patterns exhibited by Aspergillus flavus strains.*

Table 2. Clustered aflatoxin biosynthesis pathway genes showing enzymes involved, functions, statistical linear regression and efficiency.

Table 3. List of primers and the corresponding target genes used in the study.

Table S1 Integrity and quality of RNA assessed on Nano Drop spectrophotometer used for downstream analysis.

\section{Figures}




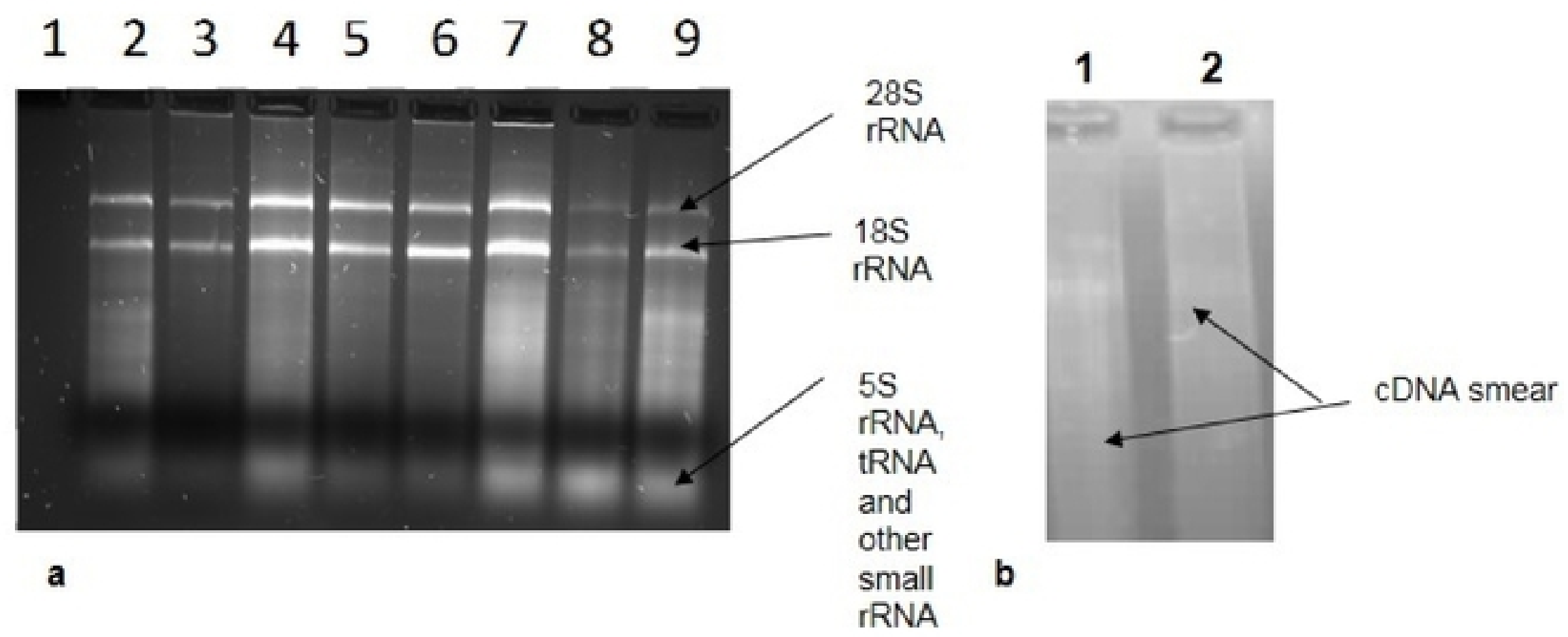

Figure $1 \mathrm{Gel}$ electrophoresis of RNA extracted from selected Aspergillus flavus strains assessed on a $1.2 \%$ agarose/EtBr gel at $80 \mathrm{~V}$ for 45 min showing; (a) Total RNA; Lane: 1 . No template (control); Lanes 2 . NC05; 3.

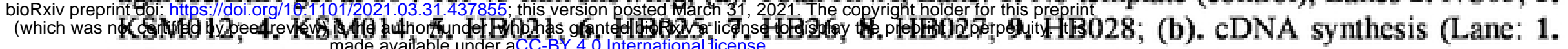
KSM012 and 2. KSM014). [(NC: Nandi county, Kenya); (KSM: Kisumu, Kenya); (HB: Homa Bay, Kenya); EtBr: ethidium bromide; cDNA: complementary deoxyribonucleic acid; RNA: ribonucleic acid]. 


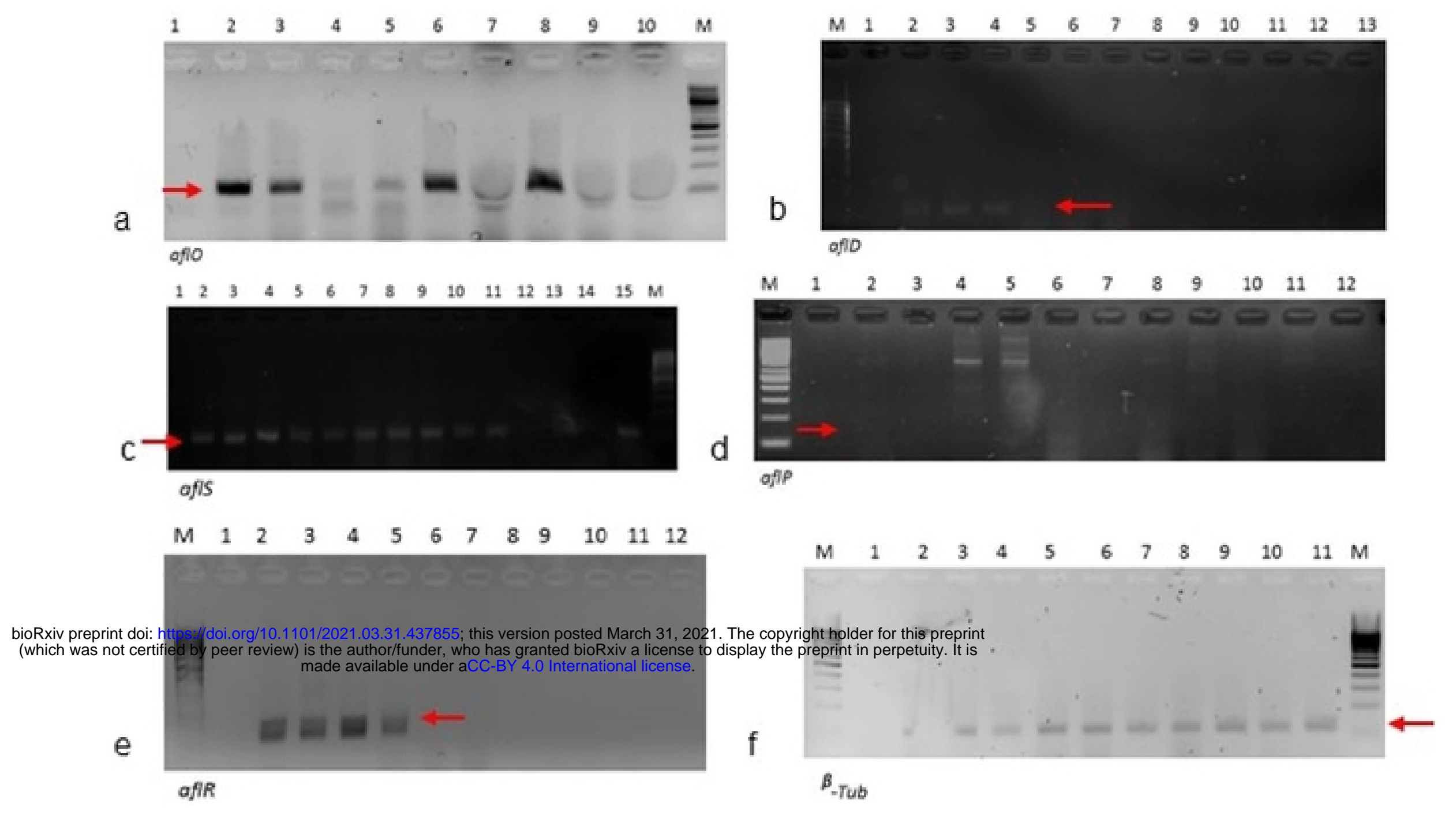

Figure 2. Gel electrophoresis of induced and uninduced isolates of $A$. flavus assessed showing qPCR product amplicon sizes of different genes run at $80 \mathrm{~V}$ for $45 \mathrm{~min}$ on $2 \%$ agarose/EtBr gel displaying various deletion patterns. M: 100 bp low range molecular marker; afl : Lane 1: NTC; 2 . Unind27; 3. Ind27; 4. Unind26; 5. Ind26; 6. Unind $21 ; 7$. Ind $21 ; 8$. Unind $14 ; 9$. Ind $14 ; 10$. Unind $12 ;$ aflD and aflR; Lane 1 . NTC; 2 . Ind $12 ; 3$. Unind $12 ; 4$. Ind14; 5. Unind14; 6. Ind21; 7. Unind21; 8. Ind26; 9. Unind26; 10. Ind27; 11. Unind27; 12. noRT; 13. noRT; aftS: Lane 1: NTC; 2. Unind27; 3. Ind27; 4. Unind26; 5. Ind26; 6. Unind21; 7. Ind21; 8. Unind 14; 9. Ind14; 10. Unind12; 11. Ind12; 12. NTC; 13. Pldstd3; 14. Pldstd2; 15. Pldstd1; aflP. 1. Pldstd1; 2. Unind27; 3. Ind27; 4. Unind26; 5. Ind26; 6. Unind21; 7. Ind21; 8. Unind $14 ; 9$. Ind 14; 10. Unind $12 ; 11$. Ind $12 ; 12$. NTC; ${ }^{\text {-Tub: Lane }}$ 1: NTC; 2. Unind27; 3. Ind27; 4. Unind26; 5. Ind26; 6. Unind21; 7. Ind21; 8. Unind $14 ; 9$. Ind $14 ; 10$. Unind $12 ;$ 11. Ind12. The isolates were cultured on inducing media (YES) and non-inducing media (YEP) (Unind: Uninduced; Ind: induced and Pldstd: Pooled standard). 

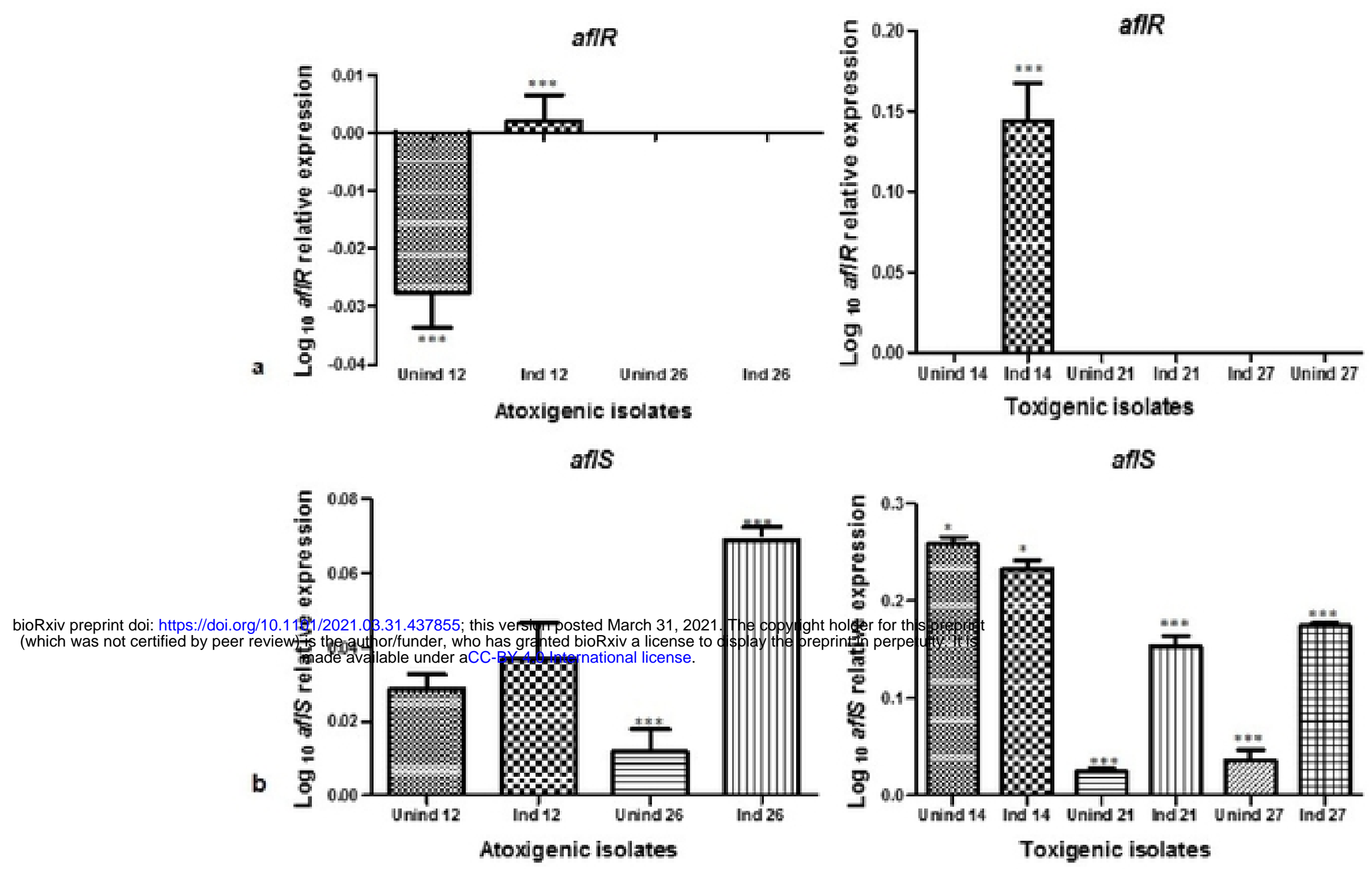

Figure 3 Expression profiles for aflR and $a f I S$. a. Significant difference in expression were noted in affR for isolates 12 and 14 (both induced), with isolate 14 upregulated significantly. Isolates HB021, HBO26 and HB027 displayed no significant expression. Uninduced isolate KSM012 was significantly down regulated. b. aflS expression profiles. The expression values were normalised, and $\log$ transformed $\left(\log _{10}\right)$. Asterisks and the error bars shows significance variance and standard mean deviations $(n=3), 1$-way ANOVA and Tukey's Multiple Comparison Test (P < 0.05). (KSM: Kisumu; HB: Homa Bay; Unind: uninduced; Ind: induced; 12-27: isolates). 


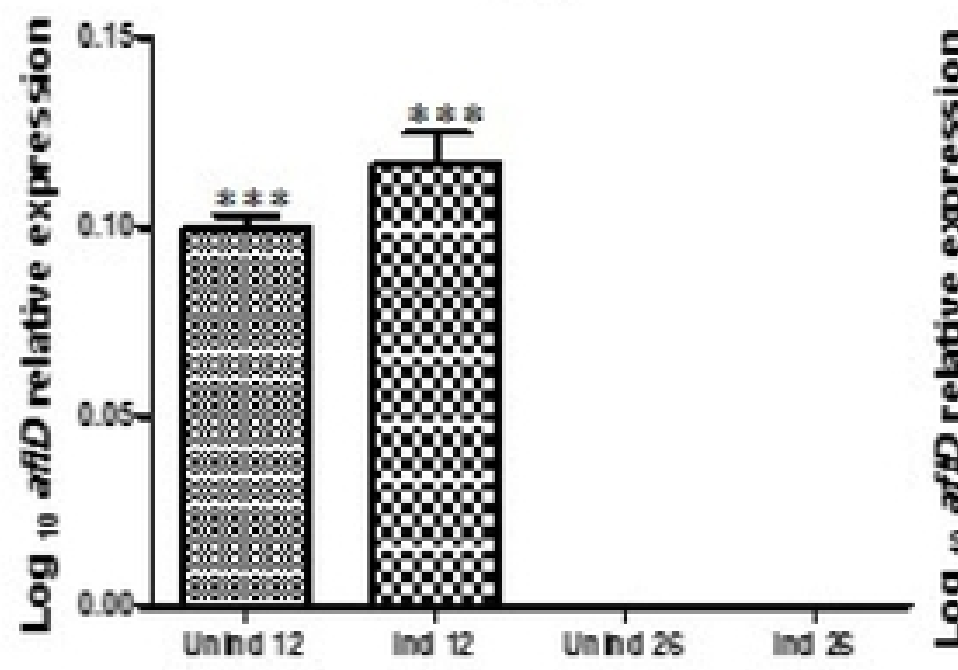

C

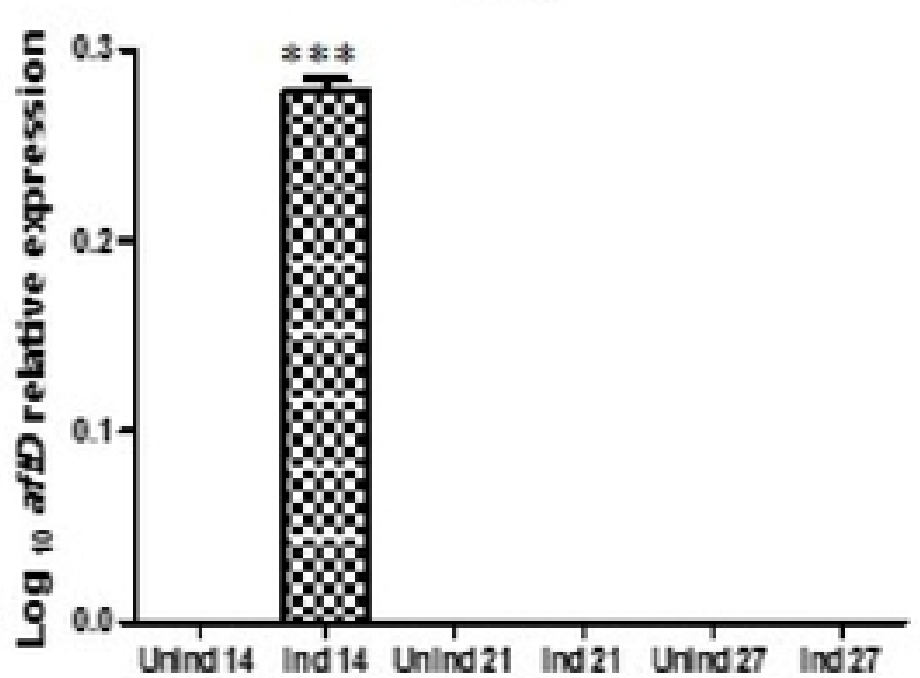

Toxigenic isolates

aflP

afP

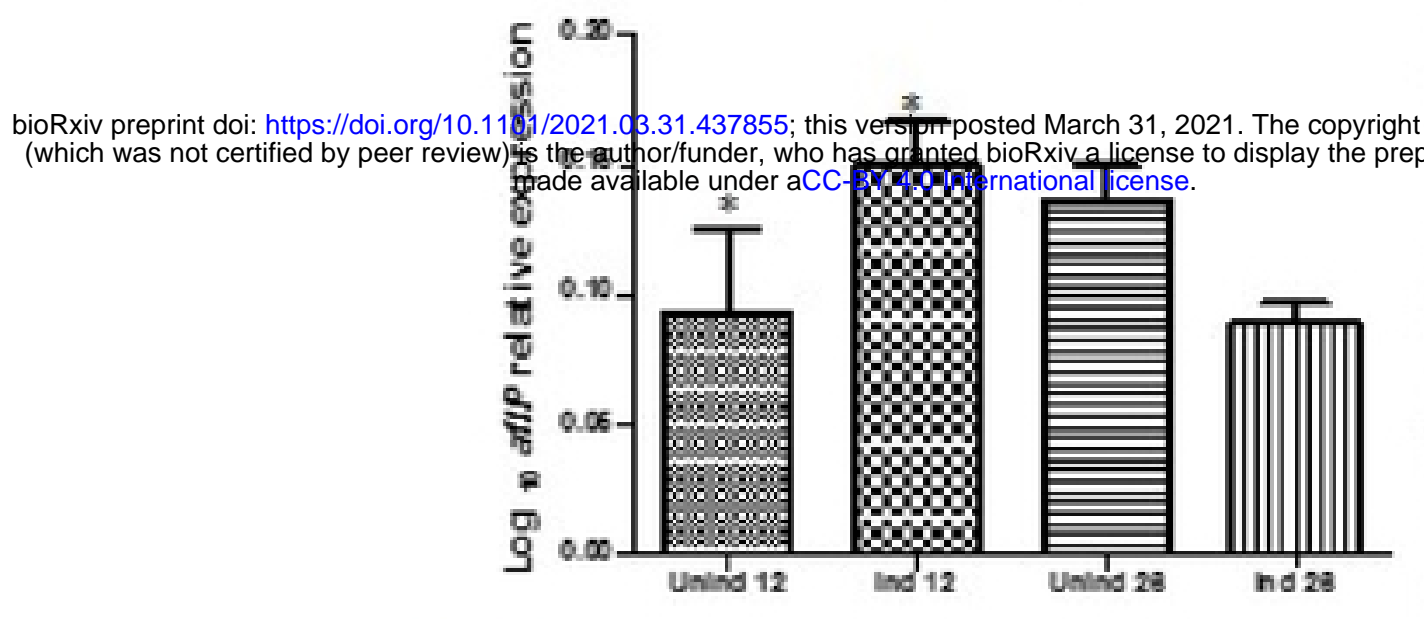

d

Atoxigenic isolates

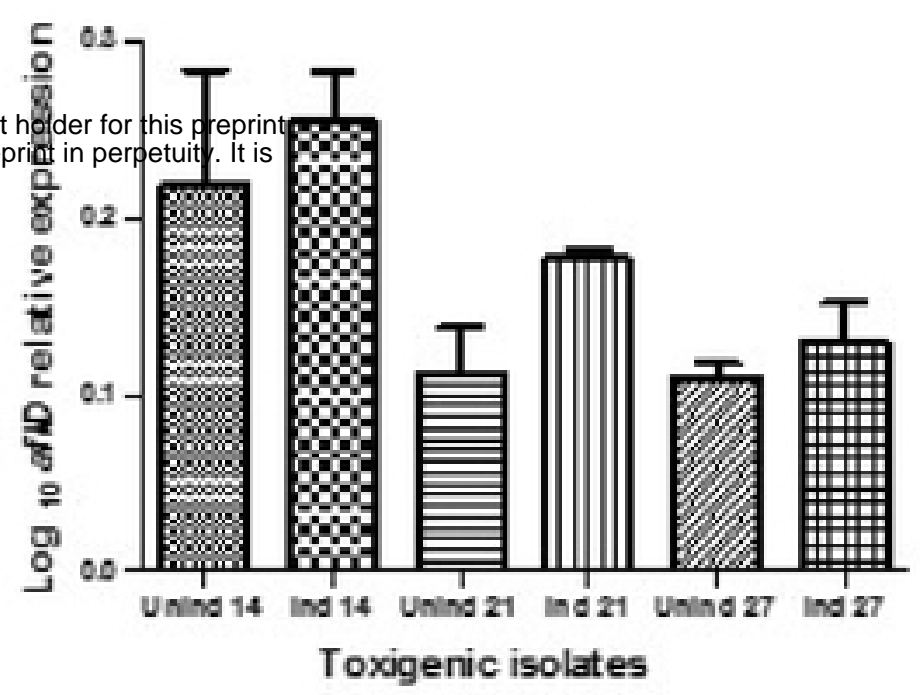

aflo

afiO
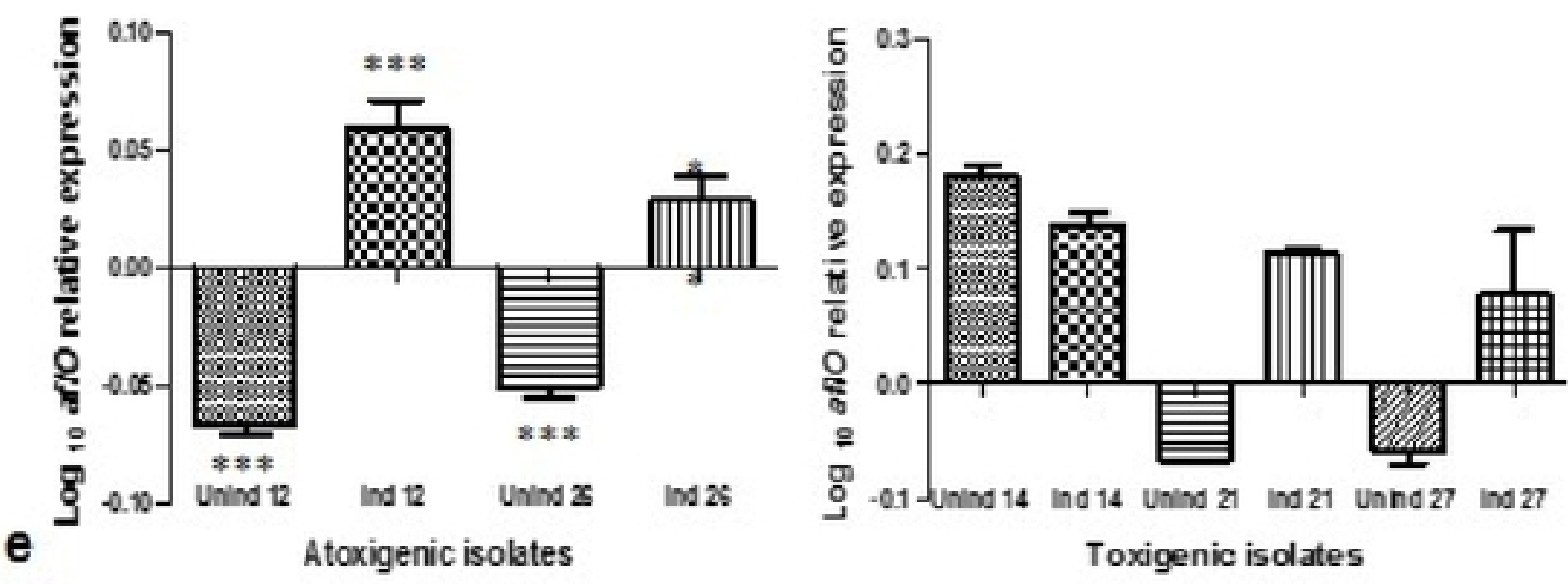

Figure 4 Aflatoxin biosynthetic gene cluster expression profiles. c. aflD expression profiles for Aspergillus flavus KSM012 and KSM014, with isolate KSM014 highly expressed. No expression was observed for isolates HB021, HB026 and HB027. d. aflP expression, which was statistically significant only for isolate KSM012. e. aflO expression profiles. There were significant difference for the atoxigenic isolates but not for the toxigenic isolates. Expression values were normalised, and log transformed $\left(\log _{10}\right)$. [Asterisks and the error bars show significance variance and standard deviations of the mean, 1-way ANOVA and Tukey's Multiple Comparison Test $(\mathrm{P}<0.05)]$. (KSM: Kisumu; HB: Homa Bay; Unind: uninduced; Ind: induced; 12-27: isolates).Significant decreases in aflR transcripts ( $\mathrm{P}<0.05$ ) were found for strains KSM012, HB021, HB026 and HB027 (Fig. 2.3a). In A. flavus $\mathrm{KSM014}$, an aflatoxin producing strain, aflR transcript abundance increased under induced and decreased under uninduced conditions (Fig.3a). Thus, aflR could be a marker to differentiate toxin and non-toxin producers. When comparing the induced isolates, isolate HB026, had higher levels of expression of aflS and aflO. KSM012 and KSM014 had higher $a f I D$ and $a f l R$ transcript levels in induced than in uninduced cultures (Figs.3; 4; Table 2). AfIR expression decreased significantly in uninduced isolate KSM012 (Fig.3a). 